\title{
Smectite appearance in the footwall of the Úrkút manganese ore deposit, Bakony Mts., Hungary
}

\author{
Máté Zsigmond Leskó ${ }^{1 *}$, Richárd Zoltán Papp ${ }^{1}$, Boglárka Anna Topa ${ }^{2,3}$, \\ Ferenc Kristály ${ }^{1}$, Tamás Vigh ${ }^{4}$, Norbert Zajzon ${ }^{1}$ \\ ${ }^{1}$ Institute of Mineralogy and Geology, University of Miskolc, Miskolc, Hungary \\ ${ }^{2}$ Department of Mineralogy and Petrology, Hungarian Natural History Museum, Budapest, Hungary \\ ${ }^{3}$ Department of Mineralogy, Eötvös Loránd University, Budapest, Hungary \\ ${ }^{4}$ Manganese Mining and Processing Ltd., Úrkút, Hungary
}

Received: July 20, 2018; accepted: December 12, 2018

The Úrkút manganese ore deposit (Transdanubian Range, Hungary) is one of the largest manganese accumulations to be formed during the Toarcian Oceanic Anoxic Event. In the past 60 years, the area was investigated intensively. The core storage facility of the manganese mine had more than 20,000 sample pieces. Most of these samples have never been investigated. During this study, which is the first widespread clay mineral study in the footwall of the Úrkút manganese ore deposit, we investigated 40 samples from seven boreholes (footwall rocks, black/gray shales below and above the first ore bed, and manganese carbonate ores). Although previous studies assumed that smectite is associated only with the ore beds, our research revealed its appearance in the footwall (Pliensbachian) as well. Simultaneously, tripoli (the local name of completely bleached chert) can also be found in the footwall. Based on the investigated samples, a sharp geochemical difference was detected between Pliensbachian and Toarcian sediments. In this paper, we try to trace the relationship between the smectite content of the footwall and the ore bed and compare these results with the observed geochemical changes. Based on the new data, we assume that the ore accumulation was caused by a flow system (upwelling-controlled ore formation).

Keywords: Toarcian Oceanic Anoxic Event, Hungary, Transdanubian Range, Úrkút, manganese deposit, smectite

\footnotetext{
*Corresponding author: Máté Zsigmond Leskó; Institute of Mineralogy and Geology, University of Miskolc, Miskolc-Egyetemváros H-3515, Hungary

E-mail: askmate@uni-miskolc.hu

This is an open-access article distributed under the terms of the Creative Commons Attribution-NonCommercial 4.0 International License, which permits unrestricted use, distribution, and reproduction in any medium for noncommercial purposes, provided the original author and source are credited, a link to the CC License is provided, and changes - if any - are indicated.
} 


\section{Introduction}

The sediment-hosted Úrkút manganese ore deposit is the largest manganese accumulation in Hungary. Mining activity lasted almost 100 years (1917-2017). The area was continuously under scientific investigation: several generations of researchers have been working there. After the end of production, there are still unexplained geologic details, which show the complexity of the deposit.

In a project between 2014 and 2016 (13 weeks during the summers), the full core storage facility of the mine was rearchived: more than 20,000 pieces of samples were photographed, repacked, and listed. The work was carried out by some 50 students from the University of Miskolc, Eötvös Loránd University, and the University of Szeged. During this work, many unique and rare samples were found, which could lead to a new wave of investigation. The main goal of our project is to understand the environmental changes that caused the ore accumulation.

Leskó (2014) found smectite below the Úrkút manganese ore deposit in the footwall. The core of our ongoing research is an extended high-resolution, sampling-based investigation, which focuses on the Pliensbachian/Toarcian boundary. We expressed our intentions to understand the environmental changes and the processes in the transition between the Pliensbachian and Toarcian. The aim of this paper is to summarize the initial investigations, which deal with the smectite content in the footwall rocks of the Úrkút deposit, and to explain the appearance of smectite below the ore deposit. Since clay minerals are very sensitive to their environment and its changes, we carried out a study of clay minerals.

\section{Geologic setting}

The Úrkút manganese ore deposit is located in the Bakony Mts., close to Lake Balaton, in the Transdanubian Range (TDR) of Western Hungary (Fig. 1). The TDR belongs to the ALps-CArpathians-PAnnonian Basin Mega unit (Csontos et al. 1992). The original location of the TDR was somewhere between the South Alpine and Upper Austroalpine lithosphere fragments (Kázmér and Kovács 1985; Haas et al. 1995; Gawlick et al. 1999; Csontos and Vörös 2004). The geologic succession of the TDR begins in the early Paleozoic with marine sediments, which underwent low-grade metamorphism. It continues with eroded sediments of the Variscan complex (Majoros 1980; Árkai et al. 1987; Fülöp 1990; Haas et al. 1995). Following Variscan uplifting and erosion (Late Carboniferous - Early Permian), regional subsidence resulted in thick continental sediments. From the Middle-Late Permian, the sediment accumulation was influenced by a regional transgression. The sea-level rise changed the type of sedimentation (Late Permian): above the siliceous continental sedimentary rocks, siliceous-carbonate rocks (marls) occur; later, the terrigenous input ceased and carbonate platforms began to be built up. By the late Triassic an extensive, coherent, few km-thick Dachstein-type platforms had developed (Haas 1988; Haas and Budai 1995; 


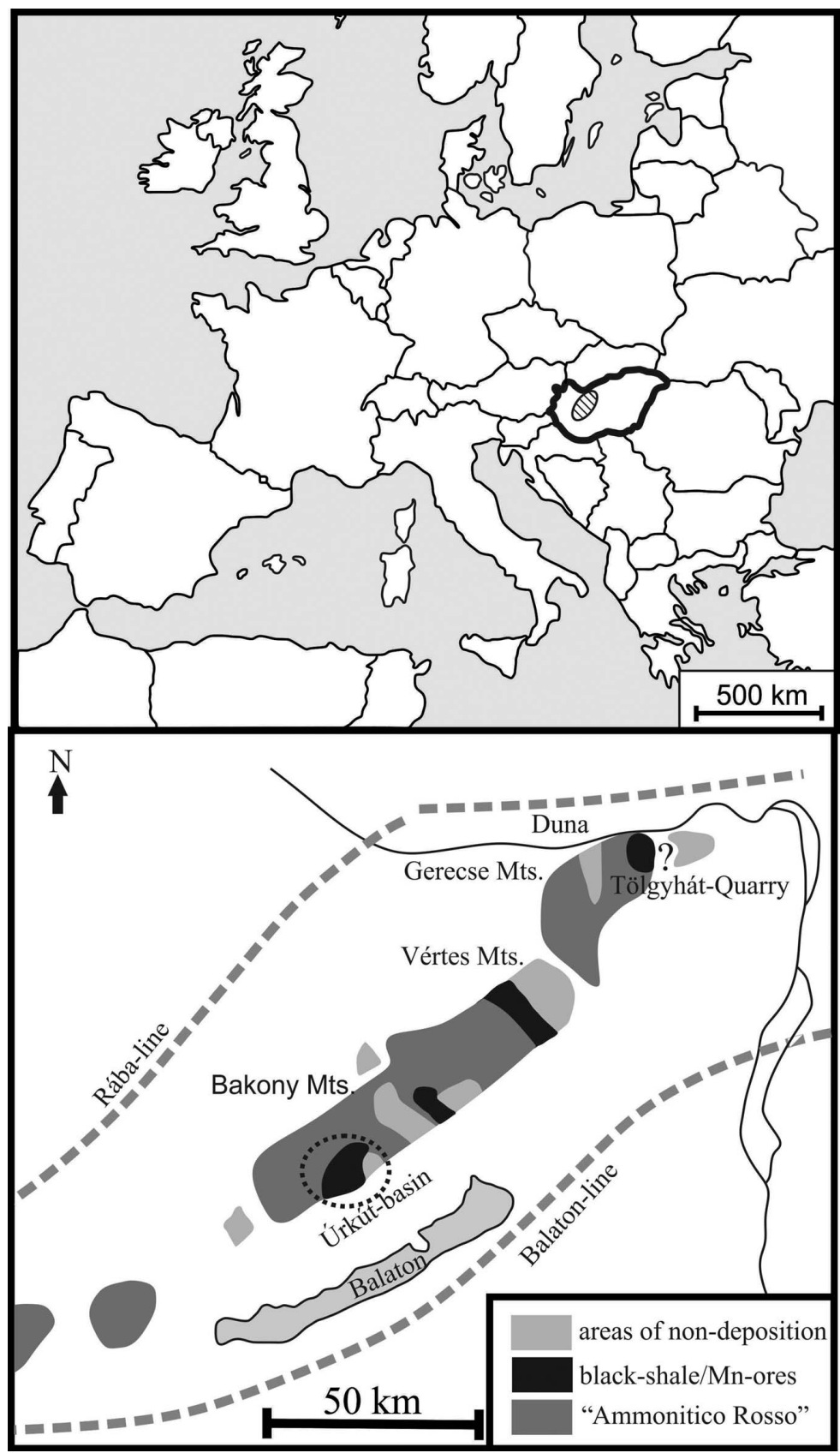

Fig. 1

Location of the Úrkút manganese ore deposit (after Vörös and Galácz 1998) 
Haas et al. 1995; Balog et al. 1997; Haas and Budai 1999; Haas 2004; Péró and Haas 2004). While extended, thick shallow-marine sediments were characteristic of the Triassic, the Jurassic sediments had more localized appearances and featured thin slope and deep-marine sediments in the TDR. In the Late Triassic/Early Jurassic, the Dachstein platform was fragmented by the spreading of the Neotethys Ocean. During the intensive extensional tectonic movements, the pieces of the Dachstein platform were drowned and emplaced into a deeper environment. The blocks ended up at various depths: there were seamounts (topographic highs) and deeper-sea basins. On the top of the seamounts, condensed red nodular limestones and hard grounds were deposited. Hierlatz Limestone (brachiopodal-crinoidal limestone) accumulated at the bottom of the slope around the heights. In the deeper basin, deep-sea sediments were formed: Ammonitico Rosso-type limestone, cherty limestones, and chert (Konda 1970; Galácz and Vörös 1972; Galácz et al. 1985; Galácz 1988; Haas 1988; Vörös and Galácz 1998; Haas 2012; Fig. 2). During the Toarcian Oceanic Anoxic Event (T-OAE; Jenkyns 1988; Jenkyns et al. 1991), black shale/gray shalehosted (Polgári et al. 2016) manganese-rich sediments were deposited in one of the aforementioned drowning basins (Szabó-Drubina 1959; Cseh Németh 1967; Szabó et al. 1981; Kaeding et al. 1983; Jenkyns et al. 1991; Polgári et al. 1991, 2000, 2004, 2012; Weiszburg et al. 2004; Szabó 2006; Horváth et al. 2014; Zajzon et al. 2014).

\section{Analytical methods}

The investigations required for this study were carried out in the Institute of Mineralogy and Geology, University of Miskolc.

$\mathrm{X}$-ray powder diffraction (XRPD) measurements were carried out using a Bruker D8 Advance diffractometer. The measurement parameters were the following: $\mathrm{CuK} \alpha$ radiation, $40 \mathrm{kV}$ accelerating voltage and $40 \mathrm{~mA}$ tube current, parallel beam geometry obtained with Göbel mirror in reflection geometry, Vantec-1 position-sensitive detector with $1^{\circ}$ detector window opening, and $0.007^{\circ} 2 \theta / 14 \mathrm{~s}$ goniometer speed. The instrumental parameters of the oriented clay mineral measurements were the same; the only difference was a longer ( $29 \mathrm{~s})$ goniometer speed. For the clay mineral investigation, the carbonate minerals within the footwall rock were dissolved in $5 \mathrm{wt} \%$ acetic acid $\left(\mathrm{CH}_{3} \mathrm{COOH}\right)$, and the $<2 \mu \mathrm{m}$ grain size was collected by gravitational separation in a distilled water column. The settling time was determined using Stokes' Law (Gibbs 1965). To prepare the oriented specimens, the pipette-on-glass-slide method (Brindley 1961; Kittrick 1961; Gibbs 1965) was used. From every sample, two specimens were prepared: both were measured in air-dried state, after which one was treated by ethylene glycol (vapor method by Brunton 1955) to determine the swelling value. The other sample was measured after 350 and $550{ }^{\circ} \mathrm{C}$ heat treatment to observe structural collapse.

The X-ray fluorescence (XRF) measurements were carried out using a Rigaku Supermini 200 wavelength-dispersive XRF spectrometer that was used with a $200 \mathrm{~W}$ Pd X-ray tube, $50 \mathrm{kV}$ acceleration voltage, and $4 \mathrm{~mA}$ tube current. The calibrated 

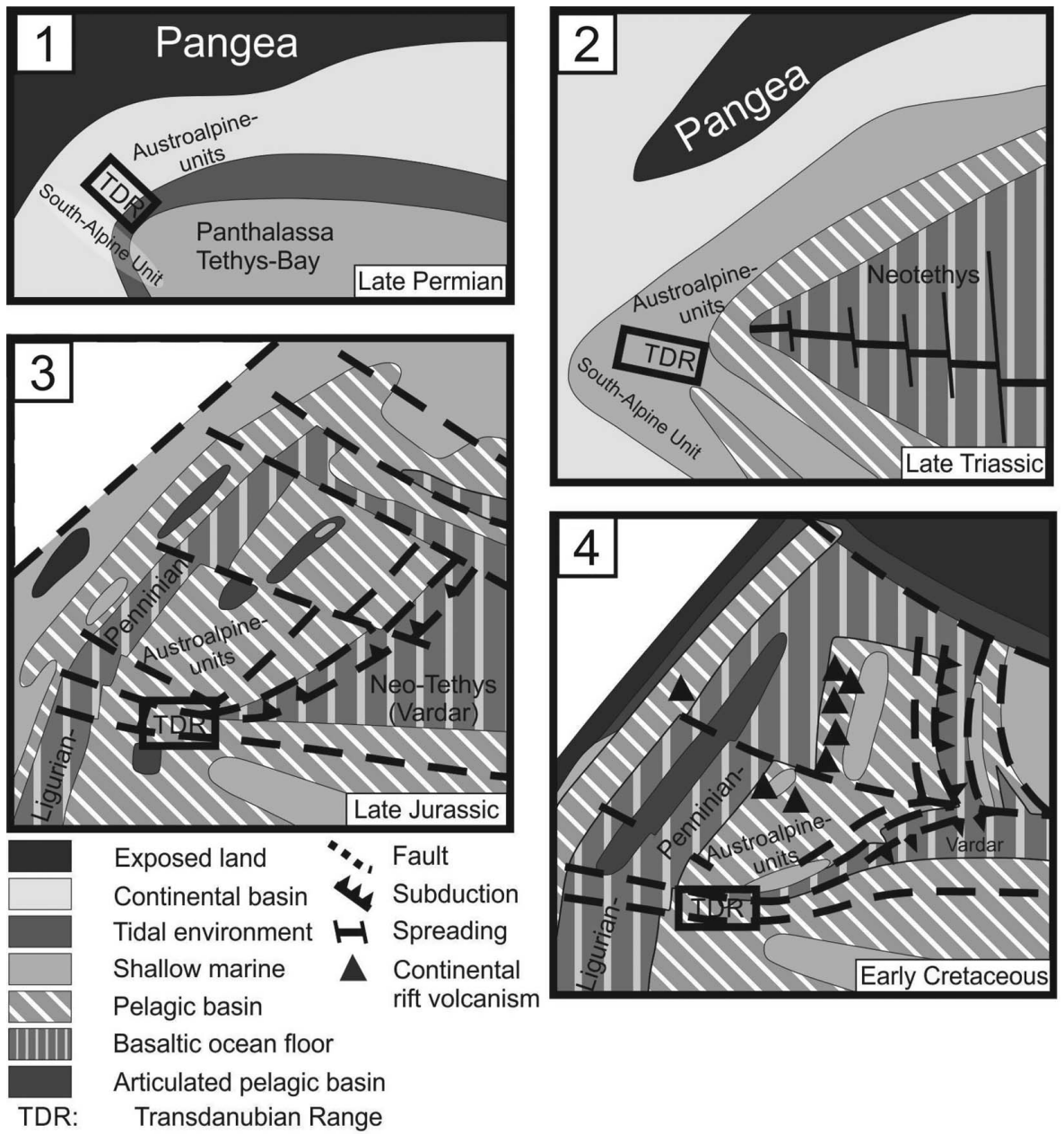

Fig. 2

The evolution of the Transdanubian Range (1, 2: after Haas 2004; 3, 4: after Péró and Haas 2004)

measurements were controlled with ZSX software (SamX, Lavardens, France). The analysis was run on pellets ( $32 \mathrm{~mm}$ diameter) made from $1 \mathrm{~g}$ of Cereox $\left(\mathrm{C}_{38} \mathrm{H}_{76} \mathrm{~N}_{2} \mathrm{O}_{2}\right)$ powder and $4 \mathrm{~g}$ homogenized bulk sample. The homogenized mixture was pressed with a 25-ton pneumatic press (Vaneox, Bedburg-Hau, Germany).

For the XRF and bulk XRPD, the samples were crushed: first $6 \mathrm{~g}$ bulk sample was crushed in a tungsten carbide breaking mortar, then the material was pulverized in a porcelain mortar, after which $1 \mathrm{~g}$ powder was separated and grinded to $<5 \mu \mathrm{m}$ in an agate mortar for XRPD measurements; from the remaining material, $4 \mathrm{~g}$ was weighted for XRF. 
The scanning electron microscopy (SEM) measurements were completed on a JEOL JXA-8600 Superprobe EMPA (Tokyo, Japan). The parameters of the measurements were $20 \mathrm{kV}$ acceleration voltage and $20 \mathrm{nA}$ beam current.

\section{Samples}

The investigated samples were selected from seven boreholes: B-180, KT-96, U-159, U-163, U-178 U-363, and UB-43 (Fig. 3). Instead of whole cores, only a representative sample was preserved from each lithology in the local core storage facility. This resulted in variable amounts of samples and a variable sample frequency in the different boreholes: sometimes only small pieces of rocks were preserved within a few meters interval; in other places, samples were available from every $20 \mathrm{~cm}$ of the core. During the sample/core hole selection, the best resolution was the main criterion,

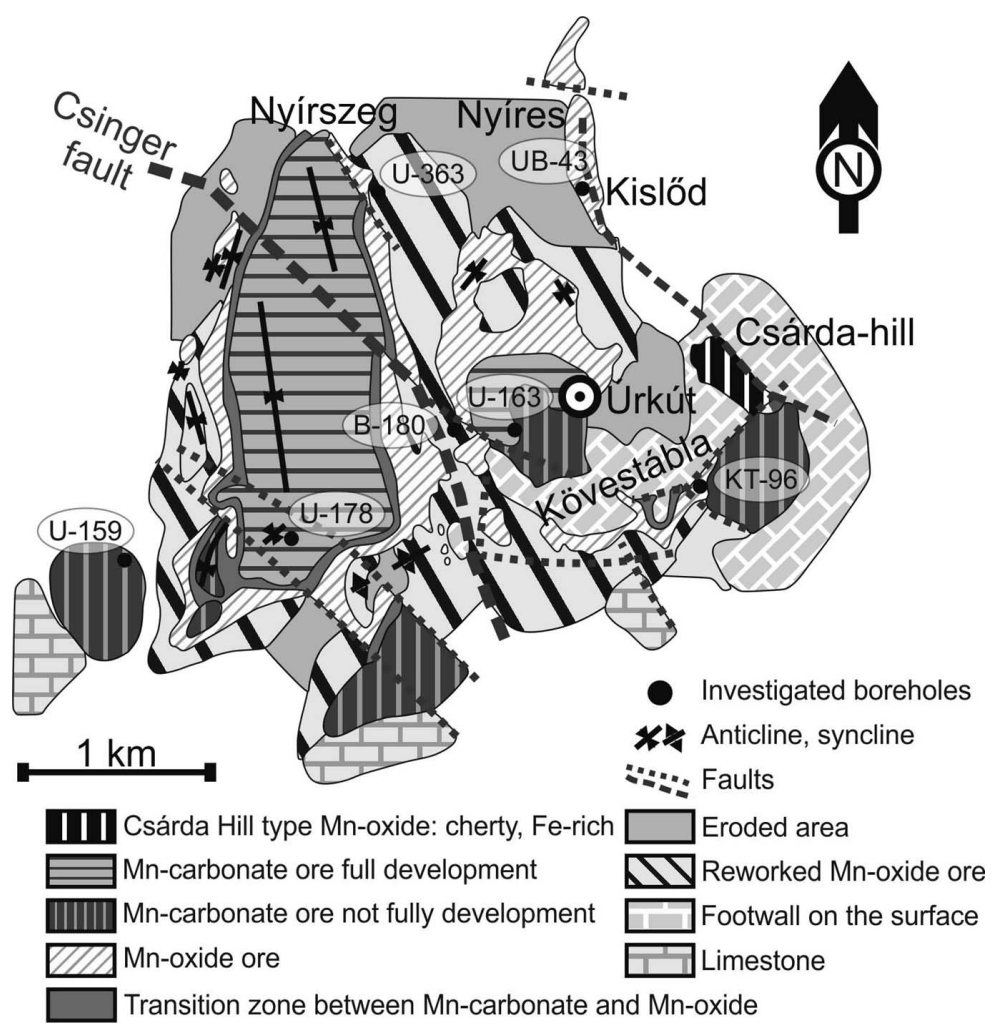

Fig. 3

Schematic geologic map of the ore deposit (after Polgári et al. 2012) 
within the footwall and in the ore body as well (Bíró et al. 2009; Bíró 2014). From the 7 boreholes, 40 samples were investigated (Table 1). $0 \mathrm{~m}$ means the beginning (base) of the T-OAE. To identify the beginning of the T-OAE, we based ourselves on the study of Bíró (2013), who reevaluated all of the archive data: drilling descriptions for all core holes, with modern lithology and formations. Where the lithology changes, from limestone to clay/Mn-oxides/Mn-carbonate, there is also a formation change from the footwall formation to the Úrkút Manganese Ore Formation. We have placed

Table 1

Description of the investigated samples

\begin{tabular}{|c|c|c|}
\hline No. of borehole & Relative depth (m) & Lithological description \\
\hline \multirow[t]{3}{*}{ B-180 } & 0.0 to 1.8 & Brown radiolarian clay \\
\hline & -1.4 to 0.0 & Cherty clay \\
\hline & -19.6 to -1.4 & Limestone with crinoids and chert \\
\hline \multirow[t]{3}{*}{ Kt-96 } & 0.0 to 0.7 & Yellow radiolarian clay \\
\hline & -11.6 to 0.0 & $\begin{array}{l}\text { Light red limestone with tripoli } \\
\text { lentil }\end{array}$ \\
\hline & -14.6 to -11.6 & Red limestone with crinoids \\
\hline \multirow[t]{5}{*}{ U-159 } & 5.8 to 6.6 & Green manganese carbonate \\
\hline & 0 to 1.5 & Clayey marl \\
\hline & -0.8 to -6.3 & Red limestone with intraclasts \\
\hline & -6.3 to -13 & $\begin{array}{l}\text { Red limestone with chert and } \\
\text { tripoli }\end{array}$ \\
\hline & -13 to -19.6 & Red chert \\
\hline \multirow[t]{7}{*}{ U-163 } & 3.35 to 3.8 & Green manganese carbonate \\
\hline & 1.6 to 2.1 & Green manganese carbonate \\
\hline & 1.25 to 1.6 & Gray/green manganese carbonate \\
\hline & 0 to 1.25 & $\begin{array}{l}\text { Light red limestone with } \\
\text { intraclasts }\end{array}$ \\
\hline & & $\begin{array}{l}\text { Light red and light green } \\
\text { limestone with intraclasts }\end{array}$ \\
\hline & -2.75 to 0.0 & $\begin{array}{l}\text { Light red limestone with } \\
\text { Mn-oxides }\end{array}$ \\
\hline & -2.75 to -5.55 & Red limestone \\
\hline
\end{tabular}


Table 1 (continued)

\begin{tabular}{|c|c|c|}
\hline No. of borehole & Relative depth (m) & Lithological description \\
\hline \multirow[t]{12}{*}{$\mathrm{U}-178$} & 6.1 to 6.7 & $\begin{array}{l}\text { Grayish green clayey manganese } \\
\text { carbonate }\end{array}$ \\
\hline & 3.8 to 5.6 & Black/gray clay shale \\
\hline & 3.1 to 3.3 & Green manganese carbonate \\
\hline & 1.6 to 2.1 & Green manganese carbonate \\
\hline & 0.6 to 1.1 & Brown manganese carbonate \\
\hline & & Black manganese carbonate \\
\hline & 0.0 to 0.6 & Black/gray shale \\
\hline & -1.9 & $\begin{array}{l}\text { Light red limestone with } \\
\text { Mn-oxides veins }\end{array}$ \\
\hline & -4.9 & $\begin{array}{l}\text { Light red limestone with } \\
\text { Mn-oxides veins }\end{array}$ \\
\hline & -9.2 & Light red limestone \\
\hline & -13.2 & Red/light red limestone \\
\hline & -14.8 & Red limestone \\
\hline \multirow[t]{6}{*}{ U-363 } & 5.1 to 6.8 & Green manganese carbonate \\
\hline & 2.6 to 5.1 & Green manganese carbonate \\
\hline & 0.0 to 2.6 & Clayey manganese oxide \\
\hline & -0.4 to 0.0 & Red clayey limestone \\
\hline & -4.4 to -0.4 & $\begin{array}{l}\text { Light red limestone with Mn- } \\
\text { oxide veins }\end{array}$ \\
\hline & -9.4 to -4.4 & $\begin{array}{l}\text { Light red limestone with tripoli } \\
\text { lentil }\end{array}$ \\
\hline \multirow[t]{4}{*}{ UB-43 } & 2.1 to 4.0 & Brown clay with Mn-oxide \\
\hline & 1.1 to 2.1 & Brown clay with Mn-oxide \\
\hline & 0.0 to 1.1 & Brown clay with Mn-oxide \\
\hline & -0.8 to 0.0 & $\begin{array}{l}\text { Hierlatz-type limestone with } \\
\text { manganese oxide }\end{array}$ \\
\hline
\end{tabular}

the beginning of the T-OAE at that point. Negative meters of depth signify that the sample originates below the T-OAE, whereas positive meters imply that the sample is younger than the beginning of T-OAE. 


\section{Results}

\section{Bulk mineralogy}

The footwall of the manganese deposit is made up of limestone. The average mineralogy of the Pliensbachian rocks is $>95 \mathrm{wt} \%$ calcite, $<5 \mathrm{wt} \%$ silicates (quartz $1 \%-3 \%$ and clay minerals $2 \%-4 \%$ ). It was necessary to use acetic acid to dissolve the Pliensbachian rocks to extract the clay mineral content. We found that after the leaching, the residual content was only $1-5 \mathrm{wt} \%$ for samples far from the Pliensbachian/Toarcian border $(>5 \mathrm{~m})$, but that within $5 \mathrm{~m}$ of that border, the amount of the residual material increased. This result is based on weighing of the residual material from the XRF and XRPD data, except in samples that contained "tripoli." Tripoli is pure recrystallized quartz, of a crumbly nature, which appears randomly within the footwall. Tripoli can be found in mm-dm-sized lenses. It does not dissolve in acetic acid, so the amount of tripoli is added to the common residual material. Approaching the T-OAE, the residual content increased ( $>10 \mathrm{wt} \%)$.

\section{Clay minerals}

The previous studies assigned the smectite only to the Toarcian sediments (black shale/gray shale and manganese ore; Kaeding et al. 1983; Viczián 1995; Polgári et al. 2013). Leskó (2014) provided the first proof that the smectite also appears just below the ore deposit $(20-30 \mathrm{~cm})$. This study led to the first widespread clay mineral study in the footwall of the Úrkút manganese ore deposit. In this work, smectite was found in the footwall (Pliensbachian limestone) in every investigated borehole and in every studied Pliensbachian rock. In Fig. 4, we present diffractograms from each borehole, from the deepest point where smectite occurred. Every sample shows some smectite content. There is a peak at $\sim 15 \AA$ in air-dried state, which is shifted to $17-17.5 \AA$ during glycolation. After heating, this peak shifted to $\sim 10 \AA$. 060 reflections show peaks at $1.505 \AA$ and $1.490 \AA$ (Fig. 5). The results indicate a dioctahedral illite and smectite. The $15 \AA$ peak is not specific to dioctahedral smectite, but it is explained by the exchange of interlayer cations to $\mathrm{Ca}$ and the water layer surrounding them, which was caused by the Ca cation exchange of the acetic acid leaching (Moore and Reynolds 1997). Besides the smectite, there was illite in every sample (peak at $10 \AA$ in the untreated samples), and some samples had kaolinite content with a peak at $7.2 \AA$, which was preserved after glycolation and heating to $350{ }^{\circ} \mathrm{C}$ but disappeared after heating at $550{ }^{\circ} \mathrm{C}$ (collapse of the kaolinite structure). Every sample contains randomly interstratified illite/smectite (Fig. 4). The deepest point below the deposit where smectite was found was $-15 \mathrm{~m}$ in the $\mathrm{U}-178$ borehole. This is also almost the deepest point in the basin that was accessed by borehole from where a sample is available, and the Úrkút Manganese Formation is here almost complete. The entry level of the smectite could not be identified because the drilling was stopped after reaching the footwall and only a few meters of Pliensbachian limestone/marl were collected. The chemical composition of the 

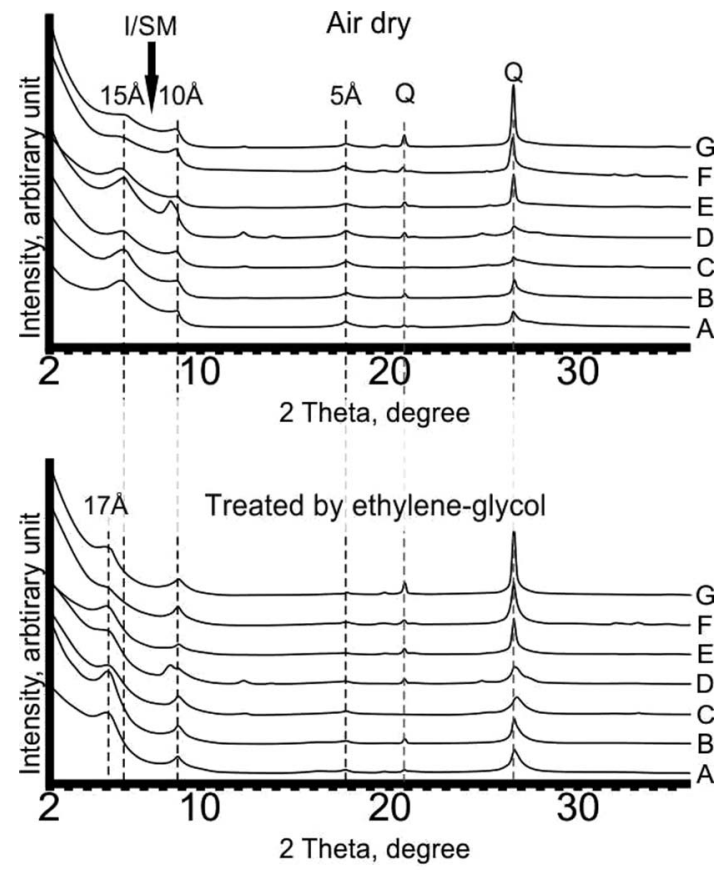
A) KT-96; B) B-180; C) U-178; D) UB-43;
E) U-363; F) U-159; G) U-163;
Q: quartz
I/SM: randomly interstratified illite/smectite

Fig. 4

XRPD results: smectite content in the footwall: smectite peaks shifting from $15 \AA$ to $17-17.5 \AA \AA$ by ethyleneglycol treating

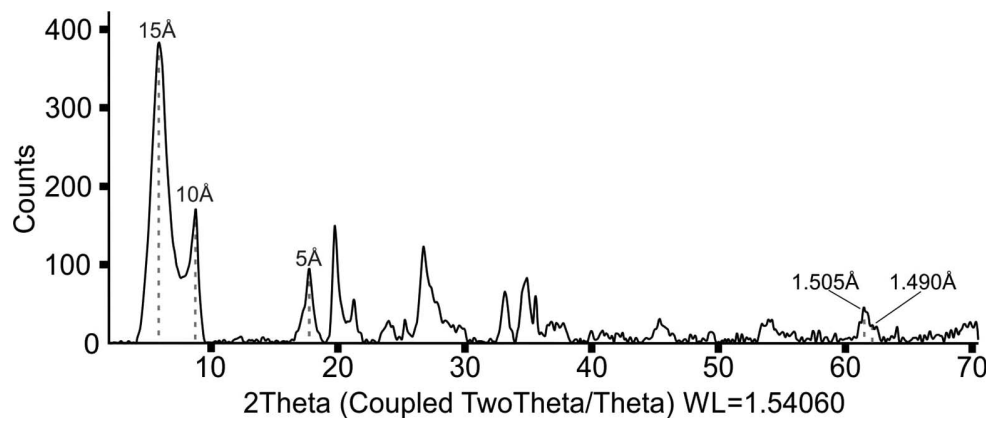

Fig. 5

Representative XRPD results from borehole U-159: 060 reflections of unoriented clay minerals (grain size less than $2 \mu \mathrm{m}$ ) 
Table 2

Representative SEM-EDS results in $\mathrm{wt} \%$ from the borehole U-178

\begin{tabular}{ccccccccccc}
\hline $\mathrm{U}-178$ & $\mathrm{Na}_{2} \mathrm{O}$ & $\mathrm{MgO}$ & $\mathrm{Al}_{2} \mathrm{O}_{3}$ & $\mathrm{SiO}_{2}$ & $\mathrm{P}_{2} \mathrm{O}_{5}$ & $\mathrm{SO}_{3}$ & $\mathrm{~K}_{2} \mathrm{O}$ & $\mathrm{CaO}$ & $\mathrm{TiO}_{2}$ & $\mathrm{Fe}_{2} \mathrm{O}_{3}$ \\
\hline \multirow{2}{*}{$-7.8 \mathrm{~m}$} & 0.41 & 5.22 & 22.09 & 58.31 & 1.49 & 0.21 & 4.20 & 2.27 & 0.48 & 4.99 \\
\cline { 2 - 10 } & 0.66 & 5.74 & 23.64 & 58.59 & 1.56 & 0.53 & 3.27 & 2.06 & 0.24 & 3.71 \\
\cline { 2 - 11 } & 0.59 & 5.42 & 23.21 & 58.85 & 1.57 & 0.38 & 3.84 & 2.25 & 0.34 & 3.55 \\
\hline \multirow{2}{*}{$-8.6 \mathrm{~m}$} & 0.72 & 5.75 & 23.54 & 58.12 & 1.49 & 0.85 & 3.26 & 1.99 & 0.40 & 4.21 \\
\cline { 2 - 10 } & 0.66 & 5.75 & 23.64 & 58.59 & 1.56 & 0.87 & 3.27 & 2.06 & 0.24 & 3.72 \\
\hline \multirow{2}{*}{$-13 \mathrm{~m}$} & 1.62 & 4.89 & 23.97 & 57.48 & 0.22 & 0.31 & 3.12 & 1.00 & 0.70 & 6.68 \\
\cline { 2 - 10 } & 1.09 & 4.40 & 24.14 & 58.01 & 0.23 & 0.19 & 3.30 & 1.05 & 0.71 & 6.89 \\
\hline
\end{tabular}

The negative number means the distance below the beginning of the T-OAE

material was measured with SEM-EDS on dehydrated materials (after $550{ }^{\circ} \mathrm{C}$ heating). The investigated samples were the same as those measured with XRPD: oriented clay mineral samples, which were made by the pipette-on-glass-slide method (Brindley 1961; Kittrick 1961; Gibbs 1965). Table 2 shows representative SEM-EDS results from borehole $\mathrm{U}-178$. Si, $\mathrm{Al}$, and $\mathrm{Mg}$ can occur within the illite and smectite as well. $\mathrm{Ca}$ appears within the smectite because of the cation exchange of the acetic acid leaching; $\mathrm{Na}$ and $\mathrm{K}$ belong to the illite. Fe can belong to the smectite and to the nanocrystalline hematite, which colorizes the limestone. $\mathrm{S}$ and $\mathrm{P}$ probably relate to the nano-sized Fe-oxide, which gives the red color to the limestone. The Ca content increases with the approach to the Pliensbachian/Toarcian border. This suggests the smectite content increases when approaching the T-OAE. No conclusion can be deducted from the changes in the Fe-content, because Fe can be found within smectite and the nanocrystalline Fe-oxide as well. The chemical formula calculation of smectite is not possible because of the small grain size: during the SEM-EDS/EPMA measurements, we analyzed at least $2-3$ phases (illite, smectite, and nanocrystalline Fe-oxide) at the same time. The clay minerals cannot be determined exactly in every detail (cation content) because during the acetic acid leaching, cation exchange and oxidation of Fe occurred.

\section{Geochemistry}

XRF measurements were carried out on samples that came from boreholes that produced at least five usable samples. These were the U-159, U-163, U-178, and 
U-363 boreholes. We focused on redox elements ( $\mathrm{Mn}, \mathrm{Fe}, \mathrm{Co}, \mathrm{Ni}$, and $\mathrm{Cr}$; Takeno 2005) because the deposit accumulated during an anoxic event: the environment was suboxic (oxygen-poor) or anoxic. These elements show high mobility under redox conditions. The main and trace element investigation shows that the studied elements were enriched only in the Toarcian sediment (during the T-OAE; Fig. 6). The U-363 borehole is an exception because there is a little enrichment just before the T-OAE. It was caused by thin Mn-oxide veins, which penetrated the footwall limestone. We found manganese veins only close to the Pliensbachian/Toarcian border $(>\sim 5 \mathrm{~m})$. The Mn-oxide occurrences are mm-thick, irregular zigzag-shaped veins, which have infiltration zones. In the Pliensbachian footwall, the amount of $\mathrm{Mn}, \mathrm{Fe}$, and trace

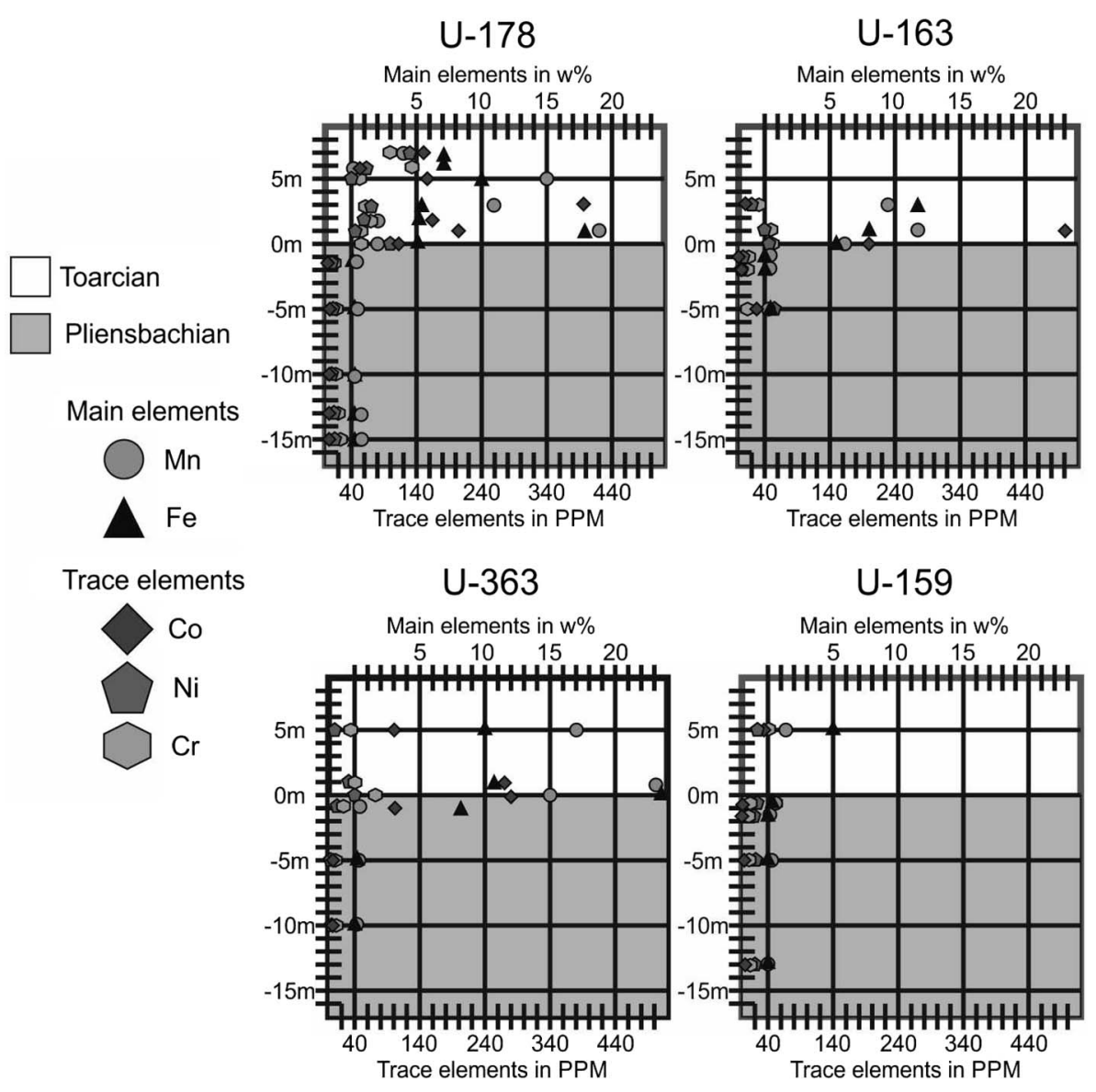

Fig. 6

$\mathrm{XRF}$ results of investigated samples of four boreholes: geochemical differences between Pliensbachian and Toarcian layers 
elements is negligible. However, from the beginning of the T-OAE, the sediments as well as the black/gray shale are enriched in these elements.

\section{Tripoli}

Tripoli is a "light-colored porous friable siliceous sedimentary rock/an incomplete silicified limestone from which the carbonate has been leached" (Jackson 1997). The Káváshegy Limestone Unit (KLU; Isztimér Limestone Formation) appears in many places just below the Toarcian strata (Bíró 2014). The KLU is enriched in red chert and has a limited range of occurrence: it appears only in the Bakony Mts. (Gyalog 1996). Tripoli was found in some footwall samples: it is visible or it was identified after acetic acid leaching. Its appearance is lenticular or massive. Tripoli is the recrystallization of the former $\mathrm{SiO}_{2}$-bearing fossils (e.g., sponges and radiolarians; Polgári et al. 2005). The XRPD measurement and the SEM investigation showed that the measured material in our sample was pure quartz (Fig. 7).

SEM investigation was carried out on polished surfaces of bulk rock and acidtreated, polished-surface tripoli.

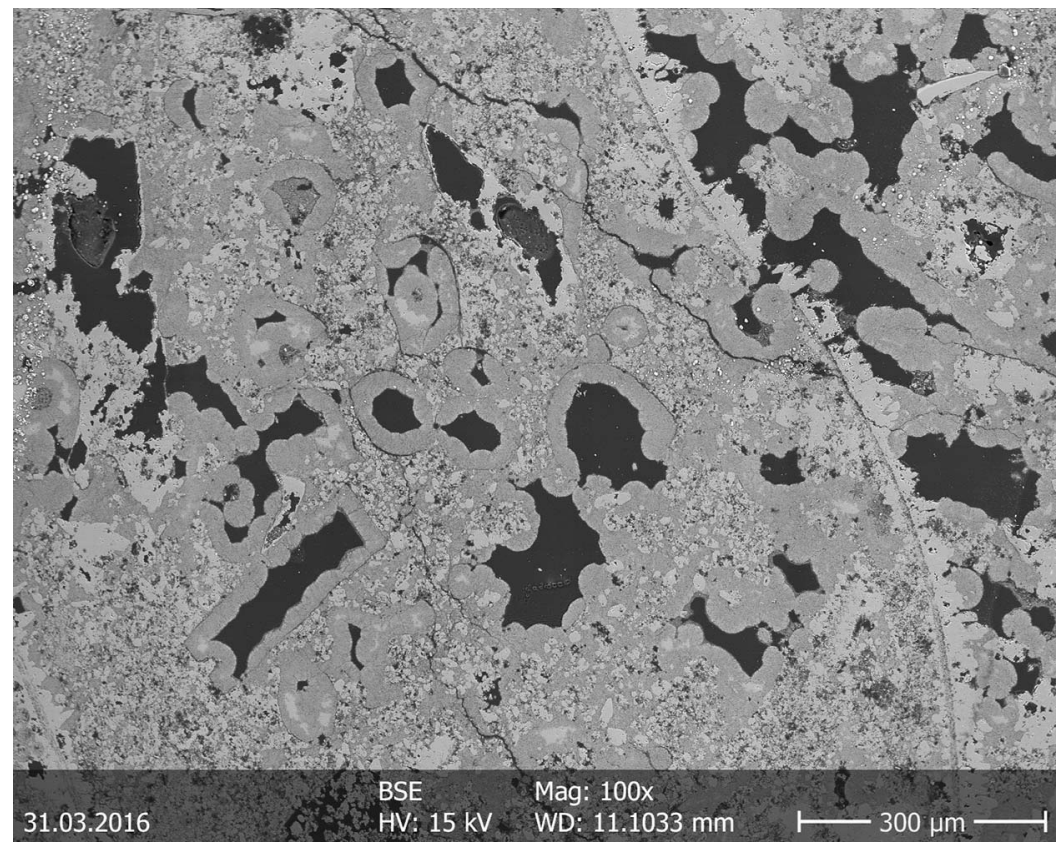

Fig. 7

SEM-BSE picture of the tripoli. Recrystallized $\mathrm{SiO}_{2}$ material within the footwall limestone 


\section{Discussion}

The Mn-oxide veins within the footwall could have been formed by the aceticleaching process mentioned first in the study of Polgári et al. (2005) and based on all our observed data. The Mn-oxide veins appear right below the deposit, penetrating only few meters into the footwall. The acidic solution cannot penetrate deep into the footwall limestone because the carbonate rocks increase the $\mathrm{pH}$; thus, the dissolving capability of the solution decreases. These observed veins and their above-proposed formation mechanism do not eliminate completely the possibility of tectonically formed Neptunian dikes elsewhere in the basin, which could well fit in the local, general tectonic environment observed, for instance in Eplény (Papp et al. 2015).

Smectite formation could take place in many ways: (a) low-temperature formation through the aging of artificially synthetized, freshly prepared hydroxide-silica precipitates (Harder 1972, 1976), whose process could happen in nature as well; (b) precipitation from hydrothermal solution (Bischoff 1972; Cole 1983; Lantenois et al. 2008); (c) alteration of volcanic rock and volcanic glass within a marine environment (Seyfried et al. 1978); and (d) precipitation from low-temperature fluids within basalt fractures (near the oceanic spreading zones; Hein and Scholl 1978; Bustillo and Martínez-Frias 2003).

In the entire TDR, there is no evidence for magmatism. There are no igneous rocks, tuffs, or volcanic glasses in the Pliensbachian or Toarcian sediments, so the third and fourth ways of smectite formation can be excluded.

Kaeding et al. (1983) refer to a hydrothermal ore and smectite formation. The main evidence was (a) the unique clay mineral content: smectite was present only within this deposit in the entire TDR in that period; (b) any trace element enrichment (e.g., Co).

We support low-temperature smectite formation through the aging of freshly formed hydroxide-silica precipitates, as described by Polgári et al. (2013); however, they identified the smectite only within the ore. The hydroxide-silica material could have been derived from the $\mathrm{SiO}_{2}$-containing fossils. This $\mathrm{SiO}_{2}$ material was recrystallized later and we can identify it now as tripoli.

There are contradictions with previous studies that assumed that smectite appears only in the Toarcian sediments within the deposit (Kaeding et al. 1983; Viczián 1995; Polgári et al. 2013). In addition, the explanations deal with two smectite formation models: precipitation from hydrothermal solution and low-temperature formation through the aging of freshly formed hydroxide-silica precipitates. There are some trace element enrichments within the deposit, which support the hydrothermal formation mechanism (Kaeding et al. 1983).

We have carried out the first widespread clay mineral study that investigated the footwall (Pliensbachian) limestone/marl of the Úrkút manganese ore deposit. We found smectite in every studied core and footwall sample, so the results of Leskó (2014) could be confirmed: smectite appears everywhere below the deposit.

In our clay mineral study, we observed that by heating the sample at $550{ }^{\circ} \mathrm{C}$, no residual peak appeared at $13 \AA$, indicating the absence of chlorite. This proves the lack 
of terrigenous sediments, which in turn confirms that the deposit was located far from the continent (Fig. 2; Meunier 2005).

Our geochemical study shows significant differences within the Pliensbachian and Toarcian sediments. In the Pliensbachian limestone/marl, there is no $\mathrm{Mn}, \mathrm{Fe}$, or trace element enrichment, but the $\mathrm{Mn}, \mathrm{Fe}$, and redox-sensitive elements show increasing values in the Toarcian rocks.

From these new results, it could be concluded that a hydrothermal origin should be excluded. If the trace element enrichment and the smectite content are connected (Kaeding et al. 1983), smectite should not appear within the footwall, as there were no elevated trace elements detected. There are two possibilities that could explain the relationship between the smectite appearance and the ore-forming process, which caused $\mathrm{Mn}, \mathrm{Fe}$, and trace element accumulation. (a) They are independent of each other; different processes caused the presence of smectite within the footwall and in the deposit and led to the ore accumulation. (b) The smectite (within the Pliensbachian and Toarcian strata) and the Toarcian $\mathrm{Fe}-\mathrm{Mn}$ and trace element enrichment are related to each other, and both formed by a single process, which could have had several phases: the first caused smectite formation during the Pliensbachian; and later during the Toarcian, the smectite formation was continued and the ore accumulated as well.

We support the second possibility: several details point to a complex flow system (upwelling controlled the ore formation): asymmetric location of the manganese-rich T-OAE-related sediments (Vörös and Galácz 1998); local appearance of the $\mathrm{SiO}_{2}$-rich footwall limestone, where the $\mathrm{SiO}_{2}$ could have come from radiolarians (Polgári et al. 2005); locally, high amount of radiolarians could represent an upwelling system (Smith 1968; Hartline 1981; Molina-Cruz 1984) and common details with other upwelling-controlled sedimentation within the TDR: radiolarite (tripoli)-containing carbonate, isolated areas connected to the opening of the Neotethys Ocean, and asymmetric sedimentation (Budai et al. 2017).

\section{Conclusions}

Our new data support the lack of any igneous event during Pliensbachian and Toarcian times in the Úrkút Basin, which was mentioned in previous studies.

The smectite content is not only limited to the ore beds but appears within the footwall in the Úrkút Basin as well. This means that the process causing the smectite precipitation began earlier, not in the Toarcian but in the Pliensbachian. If we assume that the smectite formation belongs to the ore-forming process, as the previous studies mentioned as well, we must explain why there is not any manganese accumulation during the Pliensbachian, but only in the Toarcian. The explanation is to be found in the environment changes between the Pliensbachian and Toarcian (Jenkyns 1988; Jenkyns et al. 1991). The sharp geochemical differences between the footwall rocks and the ore deposit were caused by the changing environment, particularly in oxygen fugacity. 


\section{Summary}

This paper describes the first study of clay mineral content of the footwall of the Úrkút manganese ore deposit. The investigation covered the entire area of the deposit: the measured samples also included old mining areas where production ceased more than $30-40$ years ago.

The unique smectite content of the Úrkút manganese deposit's footwall rocks and the geochemical differences between the Pliensbachian and Toarcian sediments were presented in this paper. Previous studies assumed that in the entire TDR, from the beginning of the Triassic until the end of the Toarcian (Jurassic), smectite appears only in the T-OAE-related Úrkút manganese deposit. However, all the investigated Pliensbachian footwall samples contain smectite. We identified dioactahedral smectite, illite, and in some samples minor kaolinite.

We explained the contradictions between the previous results (based on former observations, such as smectite occurrence being confined only to the ore deposit, and the enrichment of hydrothermal trace elements such as cobalt) and our new data. We assume that the ore accumulation was controlled by a complex flow system (upwelling-controlled ore formation).

\section{Acknowledgements}

This work was partially financed by the Bilateral Scientific and Technological Collaboration between Hungary (TÉT_16-1-2016-0074) project and Portugal (Fundação para a Ciência e a Tecnologia - Lisboa). This study was carried out as part of the EFOP-3.6.1-16-2016-00011 "Younger and Renewing University - Innovative Knowledge City - institutional development of the University of Miskolc aiming at intelligent specialisation" project implemented in the framework of the Széchenyi 2020 program. The realization of this project is supported by the European Union, cofinanced by the European Social Fund.

\section{References}

Árkai, P., Z. Horváth, M. Tóth 1987: Regional metamorphism of the East Alpine type Paleozoic basement, Little Plain, W-Hungary: Mineral assemblages, illite-crystallinity, $-\mathrm{b}_{0}$ and coal-rank data. - Acta Geologica Hungarica, 30/1-2, pp. 153-175.

Balog, A., J. Haas, J.F. Read, C. Coruh 1997: Shallow marine record of orbitally forced cyclicity in a Late Triassic carbonate platform, Hungary. - Journal of Sedimentary Research, 67, pp. 661-675.

Bischoff, J.L. 1972: A ferroan nontronite from the Red Sea geothermal system. - Clays and Clay Minerals 20, pp. 217-223.

Bíró, L. 2013: Complex re-evaluation of the drillings of the manganese mining in the Bakony Mountains. $\mathrm{PhD}$ thesis, University of Szeged, Szeged, $135 \mathrm{p}$.

Bíró, L. 2014: Az úrkúti mangánérc-bányászat fúrásainak sztratigráfiai újraértékelése [The stratigraphic re-evaluation of the drillings of the manganese ore mining at Úrkút]. - Földtani Közlöny, 144, pp. 3-14. (in Hungarian) 
Bíró, L., M. Polgári, T.M. Tóth, J. Kovács, J. Knauer, T. Vigh 2009: Az úrkúti mangánérc archív adatainak reambulációja [The revaluation of the Úrkút Manganese Ore's archive data]. - Geolitera Press, Szeged, 110 p. (in Hungarian)

Brindley, G.W. 1961: X-ray Identification and Crystal Structure of Clay Minerals. - Mineralogical Society of London, London, 544 p.

Brunton, G. 1955: Vapour pressure glycolation of oriented clay minerals.- American Mineralogist, 40, pp. 124-126.

Budai, T., J. Haas, A. Vörös, Zs. Molnár 2017: Influence of upwelling on the sedimentation and biota of the segmented margin of the western Neotethys: A case study from the Middle Triassic of the Balaton Highland (Hungary). - Facies, 63, pp. 22-39.

Bustillo, M.A., J. Martínez-Frias 2003: Green opals in hydrothermalized basalts (Tenerife Island, Spain): Alteration and aging of silica pseudoglass. - Journal of Non-Crystalline Solids, 323, pp. 27-33.

Cole, T.G. 1983: Oxygen isotope geothermometry and origin of smectites in the Atlantis II Deep, Red Sea.Earth and Planetary Science Letters, 66, pp. 166-176.

Cseh Németh, J. 1967: Úrkút és Eplény mangánterületeinek összehasonlítása (Ein Vergleich der Manganerzlagerstätten von Úrkút und Eplény) [Comparison of the areas of the Úrkút and Eplény manganese ore]. - Földtani Közlöny, 97/1, pp. 29-38. (in Hungarian)

Csontos, L., A. Nagymarosy, F. Horváth, M. Kovác 1992: Tertiary evolution of the Intra-Carpathian area: A model. - Tectonophysics, 208, pp. 221-241.

Csontos, L., A. Vörös 2004: Mesozoic plate tectonic reconstruction of the Carpathian region. Palaeogeography, Palaeoclimatology, Palaeoecology, 210, pp. 1-56.

Fülöp, J. 1990: Magyarország geológiája. Paleozoikum I [Geology of Hungary. Palaeozoic I]. - Geological Institute of Hungary, Budapest, 326 p. (in Hungarian)

Galácz, A. 1988: Tectonically controlled sedimentation in the Jurassic of the Bakony Mountains (Transdanubian Central Range, Hungary). - Acta Geologica Hungarica, 31/3-4, pp. 313-328.

Galácz, A., A. Vörös 1972: A bakony-hegység jura fejlödéstörténeti vázlata a föbb üledékföldtani jelenségek kiértékelése alapján [Jurassic history of the Bakony Mountains and interpretation of principal lithological phenomena]. - Földtani Közlöny, 102/2, pp. 122-135. (in Hungarian)

Galácz, A., F. Horváth, A. Vörös 1985: Sedimentary and structural evolution of the Bakony Mountains (Transdanubian Central Range, Hungary): Paleogeographic implications. - Acta Geologica Hungarica, 28/1-2, pp. 122-135.

Gawlick, H.J., W. Frisch, A. Vecsei, T. Steiger, F. Böhm 1999: The change from rifting to thrusting in the Northern Calcareous Alps as recorded in Jurassic sediments. - Geologische Rundschau, 87, pp. 644-657.

Gibbs, R.J. 1965: Error due to segregation in quantitative clay mineral X-ray diffraction mounting techniques. - The American Mineralogists, 50, pp. 741-751.

Gyalog, L. (Ed.) 1996: A földtani térképek jelkulcsa és a rétegtani egységek rövid leírása [The key of the geological maps and short description of geological formations]. - Geological Institute of Hungary, Budapest, 171 p. (in Hungarian)

Haas, J. 1988: Upper Triassic carbonate platform evolution in the Transdanubian Mid-Mountains. - Acta Geologica Hungarica, 31/3-4, pp. 299-312.

Haas, J. 2004: Magyarország geológiája. Triász [Geology of Hungary. Triassic]. - ELTE Eötvös Press, Budapest, 384 p. (in Hungarian)

Haas, J. 2012: Influence of global, regional, and local factors on the genesis of the Jurassic manganese ore formation in the Transdanubian Range, Hungary. - Ore Geology Reviews, 47, pp. 77-86.

Haas, J., T. Budai 1995: Upper Permian-Triassic facies zones in the Transdanubian Range. - Rivista Italiana di Paleontologia e Stratigrafia, 101, pp. 249-266.

Haas, J., T. Budai 1999: Triassic sequence stratigraphy of the Transdanubian Range, Hungary. - Geologica Carpathica, 50, pp. 459-475.

Haas, J., S. Kovács, L. Krystyn, R. Lein 1995: Significance of Late Permian-Triassic facies zones in terrane reconstructions in the Alpine-North Pannonian domain. - Tectonophysics, 242, pp. 19-40. 
Harder, H. 1972: The role of magnesium in the formation of smectite minerals. - Chemical Geology, 10, pp. 31-39.

Harder, H. 1976: Nontronite synthesis at low temperatures. - Chemical Geology, 18, pp. 169-180.

Hartline, B.K. 1981: Coastal upwelling: Physical factors feed fish. - Science, 208, pp. 38-40.

Hein, J.R., D.W. Scholl 1978: Diagenesis and distribution of Late Cenozoic volcanic sediment in the southern Bering Sea. - Geological Society of America Bulletin, 89, pp. 197-210.

Horváth, A., N. Zajzon, T. Vigh 2014: The distribution of REE in the Úrkút Manganese Formation. - In: S. Szakáll (Ed): Critical Monograph Series 5. University of Miskolc, Miskolc, pp. 109-130.

Jackson, J.A. 1997: Glossary of Geology (4th ed.). - American Geological Institute, Alexandria, 769 p.

Jenkyns, H.C. 1988: The early Toarcian (Jurassic) anoxic event: stratigraphic, sedimentary, and geochemical evidence. - American Journal of Science, 288, pp. 101-151.

Jenkyns, H.C., B. Géczy, J.D. Marshall 1991: Jurassic manganese carbonates of central Europe and the early Toarcian anoxic event. - The Journal of Geology, 99, pp. 137-149.

Kaeding, L., O. Brockamp, H. Harder 1983: Submarin-hydrothermale Entstehung der sedimantären Mangan Lagerstätte Úrkút/Ungarn. - Chemical Geology, 40, pp. 251-268.

Kázmér, M., S. Kovács 1985: Permian-Paleogene paleogeography along the eastern part of the InsubricPeriadriatic lineament system: Evidence for continental escape of the Bakony-Drauzug Unit. - Acta Geologica Hungarica, 28/1-2, pp. 71-84.

Kittrick, J.A. 1961: A comparison of the moving-liquid and glass-slide methods for the preparation of oriented X-ray diffraction specimens. - Soil Science, 92, pp. 155-160.

Konda, J. 1970: A Bakony hegységi júra időszaki képződmények üledékföldtani vizsgálata [Sedimentary investigation of the Jurassic formations of the Bakony Mountains]. - Annual Report of the Geological Institute of Hungary, 50, pp. 161-260. (in Hungarian)

Lantenois, S., R. Champallier, J.-M. Bény, F. Muller 2008: Hydrothermal synthesis and characterization of dioctahedral smectites: A montmorillonites series. - Applied Clay Science, 38, pp. 165-178.

Leskó, M.Zs. 2014: Ásványtani vizsgálatok az úrkúti mangánérc karbonátos és oxidos átmeneti zónájának feküjén [Mineralogical investigation of the bottom carbonatic-oxidic transition zone at the Úrkút manganese deposit]. - MSc thesis, Eötvös Loránd University, Budapest, 81 p. (in Hungarian)

Majoros, Gy. 1980: A permi üledékképződés problémái a Dunántúli-középhegységben: Egy ősföldrajzi modell és néhány következtetés [Problems of Permian sedimentation in the Transdanubian Central Mountains: A palaeogeographic model and some conclusions]. - Földtani Közlöny, 110, pp. 323-341. (in Hungarian)

Meunier, A. 2005: Clays. - Springer Press, Berlin, 472 p.

Molina-Cruz, A. 1984: Radiolaria as indicators of upwelling processes: The Peruvian connection. - Marine Micropaleontology, 9, pp. 53-75.

Moore, D.M., R.C. Reynolds, Jr 1997: X-Ray Diffraction and the Identification and Analysis of Clay Minerals (2nd ed.). - Oxford University Press, Oxford, New York, 378 p.

Papp, R.Z., B.A. Topa, T. Vigh, N. Zajzon 2015: Geochemical and mineralogical study of Eplény Mn-deposit, Hungary. - Goldschmidt Abstracts, Poster board 4063, p. 2399.

Péró, Cs., J. Haas 2004: Mesozoic evolution of the Tisza Mega-unit. - International Journal of Earth Sciences, 93, pp. 297-313.

Polgári, M., P.M. Okita, J.R. Hein 1991: Stable isotope evidence for the origin of the Úrkút manganese ore deposit, Hungary. - Journal of Sedimentary Petrology, 63, pp. 384-393.

Polgári, M., Z. Szabó, T. Szederkényi (Eds) 2000: Mangánércek Magyarországon - Grasselly Gyula akadémikus emlékére [Manganese Ores in Hungary - In commemoration of professor Gyula Grasselly]. Juhász Nyomda, Szeged, 675 p. (in Hungarian)

Polgári, M., M. Szabó-Drubina, Z. Szabó 2004: Theoretical model for Jurassic manganese mineralization in Central Europe, Úrkút, Hungary. - Bulletin of Geosciences, 79, pp. 53-61.

Polgári, M., Z. Szabó, M. Szabó-Drubina, J.R. Hein, H.-W. Yeh 2005: A porous silica rock ("tripoli”) in the footwall of the Jurassic Úrkút manganese deposit, Hungary: Composition, and origin through carbonate dissolution. - Sedimentary Geology, 177, pp. 87-96. 
Polgári, M., J.R. Hein, T. Vigh, M. Szabó-Drubina, I. Fórizs, L. Biró, A. Müller, A.L. Tóth 2012: Microbial processes and the origin of the Úrkút manganese deposit, Hungary. - Ore Geology Reviews, 47, pp. 87-109.

Polgári, M., J.R. Hein, T. Németh, E. Pál-Molnár, T. Vigh 2013: Celadonite and smectite formation in the Úrkút Mn-carbonate ore deposit (Hungary). - Sedimentary Geology, 294, pp. 157-163.

Polgári, M., J.R. Hein, L. Bíró, I. Gyollai, T. Németh, C. Sajgó, J. Fekete, L. Schwark, E. Pál-Molnár, M. Hámor-Vidó, T. Vigh 2016: Mineral and chemostratigraphy of a Toarcian black shale hosting Mn-carbonate microbialites (Úrkút, Hungary). - Palaeogeography, Palaeoclimatology, Palaeoecology, 459, pp. 99-120.

Seyfried, W.E.J., W.C.I. Shanks, W.E.J. Dibble 1978: Clay mineral information in DSDP leg 34 basalt. Earth and Planetary Science Letters, 34, pp. 265-276.

Smith, R.L. 1968: Upwelling. - Oceanography and Marine Biology Annual Review, 6, pp. 11-46.

Szabó, Z. 2006: Bakonyi mangánércek bányászata. Farkas József bányamérnök emlékére [Manganese ore mining in the Bakony Mts. In memoriam József Farkas mining engineer]. - Manganese Ltd., Úrkút, 655 p. (in Hungarian)

Szabó, Z., Gy. Grasselly, J. Cseh-Németh 1981: Some conceptual questions regarding the origin of manganese in the Úrkút deposit, Hungary. - Chemical Geology, 34, pp. 19-29.

Szabó-Drubina, M. 1959: Manganese deposits of Hungary. - Economic Geology, 54, pp. 1078-1093.

Takeno, N. 2005: Atlas of Eh-pH diagrams. - Geological Survey of Japan Open File Report, 419, 285 p.

Viczián, I. 1995: Clay mineralogy of Jurassic carbonate rocks, Central Transdanubia, Hungary. - Acta Geologica Hungarica, 38/3, pp. 251-268.

Vörös, A., A. Galácz 1998: Jurassic palaeogeography of the Transdanubian Central Range (Hungary). Rivista Italiana di Paleontologia e Stratigrafia, 104, pp. 69-84.

Weiszburg, T.G., E. Tóth, A. Beran 2004: Celadonite, the 10- $\AA$ green clay mineral of the manganese carbonate ore, Úrkút, Hungary. - Acta Mineralogica-Petrographica, 45, pp. 65-80.

Zajzon, N., L. Bokányi, H. Schupler, T. Vigh, A. Horváth, I. Gombkötő, I. Gaga 2014: Úrkút - New direction of manganese production. - In: Földessy, J. (Ed): Critical Monograph Series 10. University of Miskolc, Miskolc, pp. 128-137. 